\title{
St. Elizabeth’s Square (Námestie svätej Alžbety)
}

\author{
Author: Rudolf Jašík
}

First Published: 1958

Translations: Czech (Náměstí svaté Alžběty, 1960); English (St. Elizabeth’s Square, 1964); French (Place Sainte-Elisabeth, 1966); Ukrainian (Majdan svjatoji Alžbety, 1971); German (Die Liebenden vom St. Elisabeth Platz, 1974).

Film Adaptation: Námestie svätej Alžbety (St. Elizabeth’s Square), feature film, screenplay Štefan Sokol; film director Vladimír Bahna, premiered the 28th of January, 1966.

About the Author: Rudolf Jašík (1919-1960) was born in Turzovka in the Northwestern Slovakian region of Kysuce. He grew up in a poor family without a father. He studied at high school, but he had to interrupt his studies for financial reasons. He worked as a labourer in Zlín (1935-1938). In 1938-1940, he was unemployed and imprisoned for Communist agitation. From 1940 he had to serve in the Slovak army. 1941 he was taken to the Eastern Front where Slovakia, as an ally of Germany fought, against the Russians (he served in Crimea and Caucasus, these experiences are reflected in his unfinished trilogy The Dead Don't Sing). The Slovak army sentenced him to death in Russia for sabotage, but then he received amnesty. From 1943 to 1944 he worked for the Slovak radio. In 1944, he participated in the Slovak National Uprising against the Nazis and the collaborationist government. After World War II, he worked as a journalist in Slovakia, museum inspector in Nitra etc. He held important positions in public and in the Communist Party. In his prose, he often returned to his childhood in Kysuce and to the war.

Further Important Works: Mŕtvi nespievajú (1961, The Dead Don’t Sing; novel); Čierne a biele kruhy (1961, Black and White Circles; short stories).

\section{Content and Interpretation}

The novel is set in a small town in Slovakia during World War II. The town "under the hill with a vineyard" suggests Nitra in Southern Slovakia. The temporal setting of the story is from the summer to autumn of 1941 .

In the foreground of the novel is a tragic love story of two young people, the eighteen-year-old Slovak Igor Hamor and seventeen-year-old Jew Eva Weimannová. There are presented the pure love of two young people on the one hand, and "rusty time" of Slovak clerical Fascist regime supported by the Nazis on the other hand.

Igor and Eva stay close to each other at the edge of the town and like to meet in the tower of the church at St. Elizabeth's Square. Igor comes from a very poor family, he lives with his sick mother and survives on occasional side jobs, for instance for the 
barber Flórik, that becomes the officer of the local Hlinka Guard (the Slovak Fascist organisation). He admires his school fellow "Yellow Dodo" (wearing a yellow cap) from the underworld, but feels disgust about his dishonesty. Eva's father Samko and his partner Maxi, the Jews, own a little carriage. The situation changes when the Slovak government declares hard anti-Jewish regulations. Jews are marked with a yellow star, they lose their civil rights and the "aryanisation" begins, the expropriation of Jewish property.

Because Igor is a good person at heart and loves Eva, he tries to save her. He wants to marry her, but laws prohibit "mixed marriages". The Roman Catholic priest is willing to give her confirmation that Eva has been baptised. Nevertheless, he demands a bribe of 10 thousand crowns.

"Yellow Dodo" becomes an informer. He denounces wealthy Jews, which allegedly don't wear the yellow star. The secretary of the guard acquires their property.

The desperate Igor is looking for a big amount of money. He attempts to get money by stealing some jewellery. However, the bracelet that he has taken is only from gypsum. The young rich woman Erna Summerová that once seduced Igor, refuses to help him, as well as Eva's father Samko who is too stingy. After Igor's mother dies, Maxi, Samko's business partner, sells his two horses, and helps Igor. But now the priest refuses to baptise Eva. Shoemaker Maguš, a socialist, advises the young couple to escape into the mountains where Magušs brother will provide housing and where no one knows them. However, it is too late, the first 300 Jews from the town are gathered for the transport and Eva is among them.

Most Slovak guards try to avoid this action, therefore the Jews are watched by the German SS-men. Igor can only look helplessly on, as the German Major shoots a little Jewish boy to whom the officer has cunningly offered chocolate. Eva and two young Jewish men decide to take the boy's body away. They are also all shot dead. (This scene is not in the film version. In the film Igor pulls Eva out of the closed wagon. They run away and Eva is shot by the guards.)

Flórik cheats the rich Jew Heller with a promise to take him across the border. Flórik murders him and his family to take possession of their house and property. Eva's desperate father Samko, his wife and their son poison themselves with the strychnine. Igor wants to avenge Eva's death and kills Flórik with an iron rod. He then intends to kill himself, but the shoemaker Maguš saves him.

The novel is based on a romantic stylisation. It can be labelled as a ballad or a tragic romance. That's why the characters are quite clearly divided into positive and negative. Igor, Eva, Maguš and also Maxi on the one hand, the Slovak guards and German soldiers, Yellow Dodo, the rich Jews like Heller as well as the stingy Samko (who likes money more than his own daughter) are on the other hand. The Jews except for Maxi wear theirs stars humble like sheep. "The outcasts had learnt obedience. There was no resistance over there, in the corner, in the sheep-fold " (Jašík, 1964, p. 244). Most Slovaks laugh at guards and Hitler, but they behave passively. Igor did the only act of rebellion by killing the repulsive collaborator Flórik. 


\section{Main Topics and Problems}

The novel was inspired in part by an autobiographical experience. In September of 1941, the so-called "Jewish Codex" was declared in Slovakia. The rights of the Jews were substantially restricted. The figure of Yellow Dodo could be based on many different informers who reported Jews to the Slovak authorities to get money and property (Lônčiková, Nižňánsky, 2016). After the first edition of the novel in 1958 in Slovak, the author shortened and modified the text for the Czech edition in 1960.

The story is presented by an authorial narrator. The narrator knows everything about the past and future events in the fictional world, he comments on situations and behaviour of the characters, asks rhetorical questions and anticipates the development of the story.

The inner voices of the characters are also used. Unlike dialogues, they are clarified by only single quotation marks ( ' '). Non-living objects and things are often personified, like the tower and bells on St. Elizabeth's Square: the tower "slim and wise" is happy "to harber the lovers". On the other hand, people are frequently compared to animals. So Yellow Dodo has "snake eyes", is similar to a wolf; also Erna has "snake green eyes"; Flórik has "devilish black" hair. Germans are spiders, wolves, insects. Jews resemble sheep; Eva is similar to a caught small mouse. The whole town is depicted as ugly, black and dangerous. It seems to be a jungle where it is impossible to hide from the hunters. Against all this, the pure, exalted and glorified love of both protagonists is presented.

The novel was successful with critics and readers, because it overcame the schematic images of World War II depicted as a heroic struggle against fascism. Some critics have pointed out that the imaginative symbolism of the novel is often conventional and only decorative (Mráz, 1969, pp. 210 and 213). Flórik's triple robbery murder and burying of bodies at the end of the novel is inconsistent with his cowardly and cautious nature. Also the sneaky murder of a small Jewish child by the German Major is not believable. Nevertheless, it can be a part of the romantic balladic nature of the story.

St. Elizabeth's Square continues the topic of some previous Slovak novels, mainly Dominik Tatarka's $\rightarrow$ The Clerical Republic (1948). However, Jewish characters don't play such an important role in Tatarka's work. Jan Otčenášek's Czech novella $\rightarrow R o$ meo and Juliet and the Darkness was published 1958, in the same year as St. Elizabeth's Square. It also depicts a love between an Aryan (Czech) boy and a Jewish girl in the time of the war and Shoah with a tragic end: the death of the girl (Forst, 1974). Compared to Otčenášek, Jašík emphasises the important role of Jewish property and aryanisation. While in the Czech lands the Germans gained through aryanisation, in Slovakia the Slovaks did the same.

\section{Cited Works}

Jašik, R. (1964). St. Elizabeth’s Square. Prague: Artia. Jašík, R. (1979). Námestie svätej Alžbety. In: R. Jašík. Dielo I., ed. V. Bosáková. Bratislava: Tatran, pp. 453-708. Lônči- 
ková, M., Nižňánsky, E. (2016). Nechceš byt’ udavačom? Z dejin každodennosti slovenského štátu. In: M. Pollák, ed., Udavačstvo. Bratislava: Krásný Spiš, Kalligram, pp. 357-375. Mráz, A. (1969). Román utrpenia a dôvery. In: A. Mráz, Medzi prúdmi II. Bratislava: Slovenský spisovatel’, pp. 207-215.

\section{Further References}

Findra, J. (1971). Rozbor štýlu prózy. Prostriedky a postupy Jašíkovho individuálneho štýlu. Bratislava: Slovenské pedagogické nakladatel’stvo, pp. 60-84. Forst, V. (1974). O jednom průsečíku mezi českou a slovenskou literaturou. Tvorba, 6(36), pp. I-II. Matuška, A. (1973). Osobnosti. Bratislava: Slovenský spisovatel', pp. 328-333 and 383388. Rudolf Jašík. Seminár o živote a diele. (1979). Bratislava: Smena, 1979. Rakús, S. (1982). Próza a skutočnost'. Bratislava: Smena, pp. 92-100. Števček, J. (1989). Dejiny slovenského románu. Bratislava: Tatran, pp. 493-495. Vaško, I., ed. (1978). Rieky, hory, hviezdy a človek. Práca a poselstvo Rudolfa Jašíka. Martin: Osveta. vb (= Barborík, V.) (2006). Jašík, Rudolf: Námestie svätej Alžbety. In: R. Chmel et al., Slovník diel slovenskej literatúry 20. storočia. Bratislava: Kalligram, pp. 157-160.

$\mathrm{JH}$ 